\title{
Information systems, inter-functional collaboration and innovation in Taiwanese high-tech manufacturing firms
}

\author{
Panagiotis Ganotakis ${ }^{\mathrm{a}}$, Wan-Lin Hsieh ${ }^{\mathrm{b}}$ and James H Love ${ }^{\mathrm{a}}$ \\ ${ }^{\text {a } B i r m i n g h a m ~ B u s i n e s s ~ S c h o o l, ~ B i r m i n g h a m ~ U n i v e r s i t y, ~ E d g b a s t o n ~ P a r k ~ R o a d, ~ B i r m i n g h a m, ~ B 15 ~ 2 T Y ~}$ \\ ${ }^{\mathrm{b}}$ Aston Business School, Nelson Building, Birmingham, B4 7ET
}

\begin{abstract}
This paper investigates whether a) cross-functional integration within a firm and the use of information systems that support information sharing with external parties can enhance integration across the supply chain and wider networks, and b) whether collaboration with customers, suppliers and other external parties leads to increased supply chain performance in terms of new product development and introduction of new processes. Data from a high-quality survey carried out in Taiwan in 2009 were used, and appropriate econometric models applied. Results show that the adoption of information systems that enhance information sharing is vital not only for the effective communication with suppliers and with wider network members, but their adoption also has a direct effect across a firm's innovative effort. Cross-functional integration appears to matter only for the introduction of an innovative process. Collaboration with customers and suppliers affected a product's design and its overall features and functionality respectively.
\end{abstract}

Key words: Information sharing, Supply chain integration, Cross-functional collaboration, Supply chain performance 


\section{Introduction}

It is by now widely accepted that the internationalization of markets, competitive pricing and the increasing speed and complexity of innovation makes it difficult for individual firms to secure competitive advantage through innovation by utilizing their internal resources alone. This drives firms to alter the way they carry out business and rely more on relationships with suppliers/customers but also with a wider network of other firms and research institutions (Rungtusanatham and Forza, 2005; Chapman and Corso, 2005).

By being part of a network, firms are able to share the costs and risks of large $R \& D$ projects, work together in order to solve common new product development (hereafter NPD) problems, share information, while also being able to access a number of complementary tangible and intangible resources (Soosay et al 2008). Although this study considers collaboration with customers, suppliers, competitors/other firms and universities, special attention is put on the supply chain links due to the strong arguments about the catalytic effect that collaboration with customers and suppliers has on R\&D and NPD.

NPD and supply chain have been argued to be related to each other (Pero et al 2010) and in recent years there has been an increasing emphasis on synchronizing supply chain management with product decisions, outsourcing design activities to members of the supply chain and involving customers and suppliers in NPD efforts. It is further argued that the more information is shared within a supply chain the less time it will take for a firm to make changes under unforeseen circumstances, increasing the flexibility of operations and the introduction of new products but also organizational processes (Rungtusanatham and Forza, 2005; Sezen, 2008). 
Although collaboration within supply chain and extended network members has been argued to be beneficial for NPD, the increase in the number of participants involved in NPD projects creates a number of coordination problems that can hamper rather than assist innovation efforts (Nambisan, 2003). Indeed the switch from an internally focused NPD process to an external supply chain or network one, will mean that parts of projects will be divided among a number of partners that will have to work simultaneously, something that can only be addressed by the use of appropriate information systems (hereafter IS) (Verdecho et al, 2009).

Apart from external collaboration, it is further suggested that collaboration among internal departments (cross-functional integration) is as important for NPD and process innovation as network membership (Stroeken, 2000; Feller et al, 2005). The main argument here is that at least all (main) departments responsible for NPD need to continuously interact and exchange information on design, production requirements/thresholds as well as customer requirements in order for a commercially successful product to be developed (Bailetti and Litca, 1995; Grifin and Hauser, 1996).

Although a number of highly valuable research papers have examined through case studies how IS and cross-functional integration within a firm can enhance supply chain and wider network integration and how those and network integration itself can influence a firm’s innovative activity, some of those papers acknowledge (e.g. Feller et al 2005) that the main weakness of such case studies methods lies in the poor ability to generalize results. Moreover as Sezen (2008) suggests, most studies have been carried out in developed economies ignoring that perceived importance of information sharing in a supply chain might be different in cultures of newly industrialized countries. It is important therefore to examine factors that contribute towards supply chain/network integration 
for the case of other than developed economy countries especially given today's global supply network and the interaction between firms across the globe.

One of the world's most export orientated economies, with $70 \%$ of GDP growth generated from exports is that of Taiwan (CIA, 2011). Taiwan has long been perceived to be one of the 'four tigers' or newly industrializing countries of East Asia alongside South Korea, Hong Kong and Singapore (Hobday, 1995). According to the Global Competitiveness report (2010) Taiwan is ranked $13^{\text {th }}$ worldwide in terms of overall competitiveness and $7^{\text {th }}$ in the innovation and sophistication category. More specifically is ranked $1^{\text {st }}$ in terms of utility patents per million population, $8^{\text {th }}$ in the availability of scientists and engineers and $9^{\text {th }}$ in terms of company R\&D spending. It is not surprising therefore that the vast majority of Taiwan's exports are derived from high-tech industries such as electronics, medical instruments, as well as machinery and chemicals (CIA, 2011).

This article will focus therefore on firms in Taiwan's high-tech manufacturing industries due to the significant contribution they make to a country's competitiveness, and due to the important role that R\&D external collaborations play for them. High-tech firms have been argued to be a leading source of economic competitive advantage and industrial renewal, to increase the knowledge-intensity and science base of a country's economy and to be responsible for the vast majority of R\&D undertaken within a country (Ganotakis and Love, 2011). However high-tech sector firms have higher dependence of sales from new products (Nambisan, 2003; Ragatz et al 2002) and, given the significantly higher R\&D costs incurred in high-tech in relation to other sectors, it is vital for those firms to be able to successfully mitigate some of those R\&D costs by forming effective external collaborations. 
High technological uncertainty and complexity increases the commercial risk associated with applying such a technology on a new product. However this risk can be moderated by working with a supplier (among other firms) experienced with the specific technology or with one that is interested in further developing/exploring its applications, which can lead to the creation on innovative products. Evidence has shown that technological uncertainty and complexity has resulted in closer relationships between firms and their suppliers (Petersen et al 2003).

The main aim of this paper therefore is to provide evidence, able to be generalized to a wider population of high-tech manufacturing firms in Taiwan and perhaps other similar newly industrialized economies, on some of the main arguments of this special issue; that is (a) whether cross-functional integration within a firm and the usage of information technology that supports information sharing can enhance integration across the supply chain and wider network and (b) whether collaboration with customers, suppliers and other external parties leads to increased supply chain performance in terms of NPD and the introduction of innovative processes. The above will be investigated while taking into account firm internal resources and the industry sector a firm belongs to.

As mentioned this article will not only consider collaboration and information sharing with customers and suppliers but it will take into account external R\&D and collaborative relationships that a firm can have with other firms (e.g. competitors) and universities/research institutes. These information sources will be taken into account in order to investigate whether extracting information from non-supply chain knowledge sources can complement information extracted from 
customers/suppliers or whether they can serve as a substitute to those ${ }^{1}$. Moreover as the relationship between different information sources themselves will be known (i.e. whether drawing information from one increases the chances of drawing information from another), this will allow not only for the direct effect that an information source has on a firm's innovative activity to be investigated but also an indirect one ${ }^{2}$.

\section{Literature Review}

A number of theories and frameworks attempt to explain from different view points how a firm can gain a competitive advantage through collaboration with external parties; these include transaction cost economics (Williamson, 1975), network theories (Hakansson 1989) and more applied frameworks such as that of the innovation value chain suggested by Hansen and Birkinshaw (2007) in which almost a firm's entire set of innovation activities can be modeled. Hansen and Birkinshaw consider the innovation value chain as a "sequential, three-phase process that involves idea generation, idea development, and the diffusion of developed concepts”. Roper et al (2008) formally model the innovation value chain, and this paper will consider the first two parts of this framework; that is idea generation (gathering of information from different sources) and idea development (new product and process development) as well as the connection between the two stages.

\footnotetext{
${ }^{1}$ For example it can be investigated whether sourcing information from competitors can serve as a substitute of information derived from suppliers (and therefore using the former reduces the chances of using the latter) or whether one complements the other (using the former increases the chances of using the latter).

${ }^{2}$ For example if it was found that collaborating with competitors increases the chances of collaborating with suppliers and that suppliers affect the introduction of patents, we will also know that even if collaboration with competitors does not have a direct effect on the introduction of patents it will have an indirect one through its relationship with suppler collaboration.
} 


\subsection{Information System adoption}

Although collaboration with supply chain and other network members has been argued to be beneficial for NPD, the increase in the number of participants involved in NPD projects naturally creates a number of coordination issues. Multi-stage projects often require real-time cooperation and decision making among partners, something difficult to achieve among geographically dispersed partners (Jain et al, 2009; Nambisan, 2003).

Since the late 1980s collaboration and coordination among partner firms has been supported through the usage of appropriate IS (Jain et al, 2009) and it has been argued that the successful collaboration for the development of innovative projects among supply chain partners that need to accomplish their tasks simultaneously cannot be made without the collaboration facilitated by IT (Nambisan, 2003).

For example, Product Data Interchange (PDI) and other newer internet-based applications allow firms to simultaneously work on a joint product/process and go through its design phases faster (Wynstra and Pierick, 2000) by incorporating databases, visualization technologies and by facilitating sophisticated cross-project knowledge management (Nambisan, 2003). Customers and suppliers are therefore able to increase coordination and collaboration through the Internet something that results, among other things, in NPD as well as effective production planning and control (Chapman and Corso, 2005). Such packages applied in the NPD arena can assist in efficient and active communication among partners, enhancing problem solving and achieving higher levels of integration. Malhorta et al (2005) for example emphasized how computer - mediated collaborative technology was able to develop a radical new product and how information sharing supported by IT led to the creation of new knowledge respectively. This leads to the first hypothesis: 
Hypothesis 1: 'The adoption of information systems capable of supporting information sharing will have a positive effect on supply chain and network integration as well as the introduction of an innovative product and process'.

\subsection{Cross-functional Integration}

Although NPD originated from the R\&D department, the process is now viewed as one that involves the effective communication between a number of internal departments (Ulrich and Eppinger, 2000). More specifically, the adoption of a structure that supports cross-functional interaction especially between the design/engineering, marketing and $R \& D$ departments is perceived to be vital for the development of a commercially successful innovative product (Bailetti and Litva, 1995; Nambisan, 2003; Feller et al 2005). Those organizational departments share responsibilities for identifying market opportunities, understanding customer needs and finding the balance between engineering design and the identified customer needs. This means that sufficient interaction needs to exist between those three departments in order for the design and R\&D departments to successfully incorporate the information produced in regards to customer, production and design requirements (Bailetti and Litva, 1995). In order to achieve the above the firm needs to adopt a more flat and flexible structure that supports effective interaction (Stroeken, 2000).

A flat and flexible structure has also been associated with the creation of external collaborative linkages. Flat organizational structures have been found to assist in the formation of cross-functional teams and subsequent cross-functional integration (Duclos et al, 2003). In turn, internal crossfunctional integration and information sharing, is perceived to be a critical antecedent and be conducive to external integration (Koufteros et al, 2005). 
In order for a firm to achieve cross-functional integration, the literature suggests that linkages between departments are most often created with the usage of cross-functional teams, i.e. specialists from different departments come together to share information and make, for example, joint product and process decisions (Koufteros et al 2005). Often the goal of those cross-functional teams is to expand integrated internal processes beyond the borders of the firm by including representatives of suppliers and/or customers. This is as once internal cross-functional integration occurs within a firm, actors of such a firm are more likely to recognize that the logic that drives internal integration is also relevant and can be extended to integration and collaboration with external parties, and that in order for a supply chain to be more effective external integration is also required (Koufteros et al, 2005; Verdecho et al, 2009). Once internal cross-functional integration exists and cross-functional teams are in place, internal integrated processes can therefore be extended along a supply chain, achieving a higher level of external integration (Vichery, 2003). As argued, the adoption of a flat structure is the prerequisite of the above. Therefore:

Hypothesis 2: 'The adoption of a structure that supports cross-functional integration among a firm's departments will have a positive effect on supply chain and network integration as well as the introduction of an innovative product and process'.

\subsection{Cooperation/information sharing with supply chain members}

The often early involvement of suppliers in the design and development process of a new product is an approach that many firms are adopting in an attempt to gain competitive advantage (Furlan et al 2006). Such collaboration can involve simple consultation on design specifications all the way to giving suppliers full responsibility for improvements on the design of parts they are providing (Wynstra and Pierick, 2000; Petersen et al 2003). Suppliers can contribute to a firm's innovative 
efforts in a number of ways such as by: (1) absorbing some of the R\&D costs the buying firm would have to normally undertake; (2) transferring information, ideas and expertise on new technology and its applications; and (3) assisting in identifying potential problems and resolving them early (Ragatz et al 2002).

The integration of customer requirements into a product's design specifications is perceived to be the most important task in order for a firm to gain sustainable competitive advantage especially when the product and the technology involved is dynamic and complex (Bailetti and Litva, 1995; Bonney et al, 2007). Existing customers can be an excellent source of information, suggesting areas of new product activity which are either not being provided at all by the firm, or are currently being provided only by competitors (Ganotakis and Love, forthcoming). In general it is believed that customers can contribute to a variety of activities that can lead to the creation of a commercially successful product such as product conceptualization/ideation as well as product design, development and testing (Nambisan, 2003). Lack of customer insight was found by Bonney et al (2007) to be one of the main barriers to successful innovation.

Hypothesis 3 'Information sourcing from supply chain members will have a positive effect on the introduction of innovative products/processes'.

\subsection{Cooperation/Information sharing with competitors and universities}

Observing what competitors do is an obvious tactic for many business firms, and can be an important source of ideas for new and improved products. The main benefits of horizontal collaboration include complementing product development efforts, sharing the cost and risk of a project and the 
transferring of embedded technology and tacit knowledge (Freel, 2000). Leiponen (2005) for example found that radically innovative products are often introduced by firms that engage in information sourcing and collaboration particularly with customers and competitors. Similarly Hughes and Wood (2000) found a positive effect of interaction with competitors and the introduction of innovative products.

Allowance is also made for the influence of linkages with research institutes and universities. An enormous literature exists, much of it US-based (e.g. Mansfield 1995), all suggesting a strong positive link between university R\&D and innovation levels in different industries. By collaborating with universities firms can receive technical consulting, upgrade their research capabilities, undertake research in new fields and acquire new technology something that can have a direct impact on new product development and patent registration (Santoro, 2000). Therefore:

Hypothesis 4: 'Information sourcing from universities/research institutes or competitors will have a positive effect on the introduction of innovative products/processes'.

\subsection{Internal to the firm resources/characteristics}

Apart from the adoption of information systems and that of an appropriate structure a number of other internal to the firm variables have been suggested by the literature to affect external collaboration and a firm’s innovative activity. More specifically how a firm’s R\&D effort, size, age, group membership, employee level of skills and training, export activity and governmental support affect both supply chain and network collaboration and a firm's innovative activity will be 
investigated. For the case of a firm's innovative activity a variable capturing whether a firm has adopted a niche market strategy will also be added.

Internal $R \& D$ first of all has been found to not only contribute directly to both product and process innovation, but to also enhance a firm's ability of effectively combining externally acquired knowledge and using it in order to successfully introduce new products/processes (Roper et al, 2008). External R\&D has generally been argued to serve as a complement for a firm's internal innovative effort, to be targeted for isolated or separable aspects of a firm's operations, not to be directly related to the development of new products but rather to that of new processes (Ganotakis and Love, forthcoming).

In regards to a firm's ability/willingness to collaborate with external parties it will be expected that firms with strong internal stocks of knowledge (that is larger firms, those that belong to a group and have higher levels of employee skills and training), are less likely to need to engage in external collaboration and information sourcing as it is more likely that they will be able to gather all the information required internally (Ganotakis and Love, forthcoming). On the other hand internal resources will be expected to have a positive effect on product and process innovation (Crepon et al 1998).

Governmental assistance received specifically for $R \& D$ will be expected to stimulate external information sourcing (Edquist, 2005) and the same will be expected for exporting firms (Ganotakis and Love, forthcoming). On the other hand governmental support will be expected to supplement existing internal resources and therefore enhance a firm's innovative effort, whilst exporting firms will also be considered to have higher chances of introducing an innovative product/process either 
through learning by exporting effects or due to increased foreign competition they will have to face (Roper and Hewitt-Dundas, 2005; Grossman and Helpman, 1991).

Whether a firm is following a niche market strategy has also been regarded to enhance its innovative effort (Cooper, 1994) and therefore it will also be included in this study. Finally older firms will be expected to be more risk averse, more satisfied with the current status quo and therefore less likely to innovate (Artz et al, 2010).

\subsection{Complementarities between internal and external to the firm information sources}

The internal and external sources of information considered in this paper have been found in a number of studies to complement each other and the same will be expected in this study. For example it has been found that external R\&D complements internal, information sourcing from customers complements that of suppliers and vice versa and both are complemented by information sourcing from competitors (see Roper et al, 2008 and Ganotakis and Love, forthcoming). Those complementarities are easily explained in the sense that as firms start to learn how to manage external relationships are obtaining economies of scope and can benefit more by extending their information sourcing activities.

\section{Data}

The data are derived from the $2^{\text {nd }}$ Taiwanese Industry Innovation Survey (TIIS) carried out by the Taiwanese government between 2007 and 2009 for firms operating in the manufacturing sectors. The sample for this survey was randomly and proportionally selected from the population of firms 
operating in all manufacturing industries as these were identified by the Taiwanese government's Industry, Commerce and Service Census, something that allows for results to be generalized to the wider population of targeted firms. The survey’s derived sample includes 4563 manufacturing firms; however this paper focuses specifically on 910 high-tech firms.

In this paper the selection of high-tech sectors was based on the definition provided by the Taiwanese ministry of economic affairs (2001). The two criteria used to identify those sectors include $R \& D$ intensity and the proportion of employees in $R \& D$ activities. By applying those two criteria the following sectors were identified as high tech and are also considered as such in this study: pharmaceuticals, chemicals, computers, medical and precision machinery, consumer electronics, communication electronics and machinery and transportation equipment.

A firm's innovative activity is measured by taking into account whether a firm had reported registering a patent, a design/copyright or whether a new/improved process for manufacturing or delivering products had been introduced. These variables have been used by a number of studies (e.g. Artz et al 2010; Roper and Hewitt-Dundas, 2011) as a way of capturing a firm's innovative effort, and specifically for the two intellectual property measures, a number of arguments exist as to the benefits and drawbacks of adopting them. Patents, for example, have been argued to be one of the best measures of a firm's innovative output and to encapsulate the proprietary and competitive dimension of a firm's technology as minimal standards of novelty, originality and potential use have to be fulfilled. They are also perceived to be an outcome of that part of the firm's innovative effort with a considerable expected commercial value as firms are more likely to patent inventions, given the high cost and effort of patenting, with the potential to be commercially exploited (Archibugi and Pianta, 1996; Artz et al, 2010). 
Moreover a number of studies (e.g. Artz et al 2010) have found an association between patents and the introduction of innovative products, while Roper and Hewitt-Dundas (2011) found that an association exists only when the existence of patents is complemented with acquisition of technical knowledge from external sources. In conclusion, given the above arguments and evidence, we are confident that patents and copyrights/designs present reliable measures of a firm's innovative effort.

Table 1 provides a description of the variables used in the analysis, and shows descriptive statistics for the high tech sample as well as for the whole sample (including the high-tech sectors). For the case of the high-tech sample of firms and in regards to innovative activity, $56.9 \%$ of the sampled firms had introduced an innovative process whereas $52.9 \%$ had registered a patent and $45.71 \%$ a design/copyright. The adoption of information systems capable of supporting the sharing of information/knowledge with external parties was measured in the survey by using a variable capturing the non adoption or the low, medium or high extent of usage of such an IS. For the purposes of econometric estimation this ordinal variable was recalculated, taking the value 1 where firms made high use of such an IS system and zero otherwise. The variable for diffusion of a structure that assists cross-functional integration was measured in a similar way. $17.58 \%$ of firms had adopted an IS at the high level and $13 \%$ reported that the extent of diffusion of such a structure was high. Finally $74.1 \%$ and $70 \%$ of the high-tech firms were found to share information with customers and suppliers respectively.

\section{Method}

As firms can simultaneously select to share/obtain information from a variety of sources it is important to consider estimating the process of information sharing simultaneously and in this case 
the most efficient approach from an econometric point of view is the usage of a multivariate probit (MVP) model. However, as Greene (2005) notes, the statistical efficiency gains derived from the usage of a MVP are reduced in situations where the different equations consist of similar variables. This situation arises in the present paper as the variables that are used to predict each information sharing activity are similar, with the added dimension of investigating for simultaneity between the information sourcing activities. Second, in practice, the successful estimation of an MVP automatically places some limits on the degree of simultaneity which it is possible to include. In the present model this is particularly undesirable because a key area of interest is the complementary or substitute relationship between knowledge sourcing activities. Third, the derivation of marginal effects, which are important for understanding the innovation value chain, is less straightforward with MVP than with simpler modeling frameworks. Instead of using MVP a simpler approach is therefore adopted using six single equation probit models. This approach, while sacrificing some statistical efficiency, provides substantial gains in terms of the ability to reflect more fully the relationship between information sourcing activities and the ability to identify readily interpretable marginal effects. Therefore six equations will be estimated each one having as a dependent variable each of the following six variables: whether a firm shared information with (1) customers, (2) suppliers, (3) competitors (and other firms), (4) research institutes/universities and whether a firm carried out (5) internal and (6) external R\&D.

In regards to the equations that investigate the determinants of a high tech firm's innovative activity as the dependent variables are again binary indicators (i.e. whether a firm has introduced a new process, and whether it has registered a patent or copyright/design) simple bivariate probit models will also be applied here. Marginal effects (i.e. the effect that an independent variable will have on 
the dependent in terms of increased or decreased probability that the dependent variable will occur) are reported throughout all models used.

\section{Results}

\subsection{Determinants of information sharing}

Starting with the results regarding information sharing, a number of issues are of interest at this stage. First whether (a) having adopted an IS that can support sharing/communicating information, knowledge and skills with other firms and (b) having adopted a structure that promotes cross functional integration within a firm, can both enhance communication across the supply chain as well with other extended network parties. Whilst investigating the above it will also be examined whether collaborating with external parties other than customers and suppliers and carrying out external and internal R\&D increases or decreases the probability of a firm sharing information within a supply chain. An increase in the probability will indicate that carrying out internal and external R\&D or collaborating with other external parties allows a firm to gain access to knowledge that complements that which can be drawn from within the supply chain, whereas a decrease will indicate that knowledge from those parties can serve as a substitute. Finally other factors that determine information sharing across the supply chain will also be considered.

Results (table 2) show that having adopted an IS that can support information sharing with external parties can significantly increase the probability of sharing information with suppliers but not with customers. On the other hand, having adopted an organizational structure that facilitates crossfunctional integration does not appear to assist in information sharing upstream or downstream 
within a supply chain. Moreover findings suggest that information sharing with customers also leads to information sharing with suppliers and vice versa, indicating that once firms have started to collaborate upstream or downstream in a supply chain they are more likely to be completely integrated within a supply chain in terms of information sharing. This also shows that information from customers complements information derived from suppliers (and vice versa) rather that substituting it, i.e. Taiwanese high tech firms draw and share different type of information for new product development from their customers than they do from their suppliers.

In regards to the relationship between customers, suppliers and other knowledge sources, interaction with competitors/other firms enhances the probability of information sharing with both customers and suppliers whereas interaction with universities/research institutes interacts with suppliers alone. Internal and external $\mathrm{R} \& \mathrm{D}$ appear to complement each other, and sourcing information from competitors/other companies complements internal R\&D whereas information from universities complements only external R\&D. The full network of relationships is portrayed in Figure 1. Numbers above arrows represent probabilities that using one source will lead to the usage of another.

In terms of the other determinants of information sharing, firms that have trained employees specifically for the introduction of an innovation are more likely to start sharing information with suppliers and carry out internal R\&D. Firms that received governmental support for the introduction of an innovation are more likely to use those funds to outsource $R \& D$ in the expense as it seems of exchanging information with suppliers. Finally younger firms are more likely to carry out internal $R \& D$ whereas older are ones more likely to engage in information sharing with competitors/other companies. Larger firms are more likely to collaborate with research institutes/universities and carry out internal $R \& D$ however for the latter after a certain size the probability of carrying out $R \& D$ 
decreases. Finally exporting firms are more likely to carry out internal R\&D.

\subsection{Determinants of product innovation}

The next stage of the analysis investigates the transformation of information derived from internal and external sources into innovation output; in this case whether a firm has registered patents, designs/copyrights or whether a new process for the development or/and delivery of products has been introduced by the firm. Results are presented in table 3.

Information sourced from supply chain partners appears to be important for both patent and design/copyright registration; information sourcing from customers leads to the registration of patents (increase in probability by $9.43 \%$ ) whereas information from suppliers leads to the registration of designs/copyrights (increase in probability by $7.97 \%$ ). The adoption of information systems capable of supporting inter-firm communication and information sharing and the implementation of organizational structures that assist in intra-firm communication proved to be vital for the introduction of most forms of innovation. More specifically, both were found to increase the probability (IS by $8.35 \%$ and structure by $8.34 \%$ ) of a firm introducing a new process for the development/delivery of products. Moreover the adoption of IS was found to also positively affect the probability of a firm registering a patent (9.46 \%) and copyrights (11.95\%).

Internal $\mathrm{R} \& \mathrm{D}$ as well as information sourced from research institutes/universities was found to contribute to both patents and copyright/design registration whereas external R\&D matters for the introduction of innovative processes. The relationships between information sources and innovative outputs can be observed in Figure 2. Numbers above arrows represent the increase in probability of 
having an innovation output for each information source. Moreover as universities have a direct effect on both intellectual property measures, and as information sourcing from suppliers increases the probability of collaborating with universities, it appears that information derived from suppliers apart from the direct effect it has on the probability of copyright registration it also indirectly influences both patent and copyright registration through universities.

In terms of the rest of the variables affecting innovation, older firms and firms that export or have adopted a niche market strategy are more likely to list a patent whereas firms that are members of a group are less likely to do so. Niche market strategy also increases the chances of registering a design/copyright as does a skilled workforce.

\section{Discussion}

Hypothesis 1 is strongly supported by the results: the adoption of IS designed to assist effective information sharing among external to the firm parties was found to significantly increase the probability of a firm collaborating with suppliers, research institutes/universities but also to enhance the probability of carrying out internal R\&D. IS adoption also appeared to directly influence all three measures of a firm's innovative output considered in this study, i.e. process innovation, patent and copyright registration. Results therefore agree with the suggestions of a number of researchers who argued that the adoption of appropriate IT is vital in order for a firm to be effectively integrated into a supply chain or wider network and in order for all the parties involved in that network to successfully coordinate their activities for the completion of a project that involves NPD or the introduction of an innovative process (Nambisan, 2003; Jain et al 2009). 
On the other hand there is weak support for Hypothesis 2. Cross-functional integration was found to only increase the probability that a firm will introduce an innovative process and had no effect on external information integration or product innovation. It appears therefore that for Taiwanese hightech manufacturing firms inter-departmental communication is carried out mainly as a means to identify ways for improvement of functions and processes and less with communicating information that has to do with NPD. Although inter-departmental communication regarding the improvement of processes can enhance firm efficiency and reduce waste, the non-significant effect of this variable with either patent or design/copyright registration means that high-tech Taiwanese firms at the very least do not combine information regarding advancements in technology and/or design with customer preferences effectively, something that can have an adverse effect on the marketability of innovative products (Bailetti and Litva, 1995; Feller et al 2005).

Hypothesis 3 is partially supported: although collaboration with customers and suppliers increased the probability of patent and copyrights registration respectively, both those variables had no significant effect on process innovation. The fact that suppliers directly influenced design/copyright registration agrees with existing suggestions and findings (Wystra and Pierich, 2000; Ragatz, 2002; Petersen et al 2003; Rungtusanatham and Forza, 2005), that involvement of suppliers in the design process of a product, either through simple consultation or full responsibility for the design of a specific part of the product, is more likely to lead to a product that delivers greater value to the customer. On the other hand it contradicts earlier evidence that firms collaborate with their suppliers mainly for process rather than product improvement (e.g. Wong, 1992). The finding that collaboration with customers increases the probability of patent registration is in line with studies that argue that information derived from customers can be a valuable source of product idea 
generation and that customers can be instrumental in the research, development and testing of an innovative product (Nambisan, 2003).

Finally, partial support is also found for Hypothesis 4, as collaboration with research institutes/universities significantly affected both product innovation variables giving support to studies arguing in favour of such a relationship (Mansfield 1995; Santoro, 2000). Information sharing with competitors was not found to have a direct effect on any of the three innovation variables. However these direct effects from knowledge sourcing are not the whole story. In addition to their direct payoffs, firms' information sourcing activities may also be having an indirect effect through their complementarity with other knowledge sourcing activities (Table 2). For example, an indirect effect was indeed observed between collaboration with competitors and patent and design/copyright registration. Table 2 shows that if a firm shares information with competitors it is more likely that will also share information with suppliers, customers and is also be more likely to carry out internal R\&D. As already mentioned supplier collaboration has a direct effect on design/copyright registration, customer collaboration on patent registration and internal $\mathrm{R} \& \mathrm{D}$ on both. It is evident therefore that although no direct effect between competitors and product innovation variables can be observed an indirect one through the aforementioned variables does exist. Similar results were observed in Ganotakis and Love (forthcoming).

\section{Conclusions}

The main aim of this paper was to provide evidence that can be generalised to the wider population of high-tech firms in an advanced developing economy in regards to (a) whether the adoption of information systems that support information sharing with supply-chain and other external network 
parties and the adoption of a flat structure that allows cross-functional integration can enhance information integration among the firm and those parties, and (b) whether collaboration with the aforementioned parties leads to the introduction of innovative products or/and processes.

In order to achieve this, data from a high quality survey carried out by the Taiwanese government in 2009 were used, and appropriate econometric models were applied. The key findings are as follows. The adoption of information systems that enhance information sharing not only with members of the supply chain but other external parties is vital not only for the effective communication with suppliers and with wider network members, but their adoption also appears to have a direct effect across a firm's innovative effort. On the other hand the implementation of a flat structure that supports cross-functional integration appears to matter only for the introduction of an innovative process. Internal R\&D effort appears to be essential for product innovation as is collaboration with customers and suppliers, with the latter having an effect on a product's design and the former on its overall features and functionality. External R\&D appears to complement internal one and to be used mainly for the introduction of internal innovative processes. Collaboration with external research institutes/universities appears to also be important for NPD. Finally internal and external information sources appear to be complementary with each other, something consistent with earlier studies (e.g. Ganotakis and Love, forthcoming; Roper et al, 2008).

\subsection{Implications}

The results have a number of managerial implications. First of all it appears that Taiwanese high-tech firms that want to develop a competitive advantage should not only invest in internal R\&D but should also form collaborative agreements with both customers and suppliers and also when possible 
with universities and external research institutes as they are proven here to be sources of complementary knowledge. Thus even where the direct outcomes of knowledge sourcing activities on innovation are insignificant, as in the case of external $R \& D$ on product innovation, their overall influence may still be positive due to a complementary relationship. For example, external R\&D is complementary to internal R\&D (see Table 2), suggesting that investment in external R\&D can bring indirect innovation, even if external $R \& D$ involvement appears to directly influence only process development. Moreover in order for communication among supply chain members to be effective, information systems that can support information sharing for the purposes of product and process development need to be adopted. Flat organizational structures that support inter-functional information sharing are important for the introduction of process innovations.

\subsection{Limitations and future research}

Our study does, of course, have a number of limitations that need to be acknowledged. Although the paper answers calls made by the research field for studies to be carried out that investigate the role of cross-functional integration and IS on supply chain integration and performance, and although its aim as described in the first paragraph of this section was achieved, the study would have further benefited from qualitative data that could have given more insight on the type of information communicated through IS with customers and suppliers, and the mechanisms that link crossfunctional collaboration with external collaboration and NPD. Moreover unfortunately the survey did not include further information on the type of IS adopted by the firm something that could have added more detail in the analysis and discussion. It is suggested therefore that studies that make usage of both high quality quantitative and qualitative information can further advance the field. 


\section{References}

Archibugi, D. and Pianta, M., 1996. Measuring technological change through patents and innovation surveys. Technovation, 16, 451-468.

Artz, K.W. Norman, P.M. Hatfield, D.E. and Cardinal, L.B., 2010. A longitudinal study of the impact of R\&D, patents, and product innovation on firm performance. Journal of Product Innovation Management, 27, 725 - 740.

Bailetti, A.J. and Litva, P.F., 1995. Integrating Customer Requirements into Product Designs. Journal of Product Innovation Management, 12, 3 - 15.

Bonney, L. Clark, R. Collins, R. and Fearne, A., 2007. From serendipity to sustainable competitive advantage: insights from Houston's Farm and their journey of co-innovation. Supply Chain Management: An International Journal, 12, 395 - 399.

Cooper, R.G., 1994. How new product strategies impact on performance. Journal of Product Innovation Management, 1, 5-18.

Crépon, B. Duguet, E. and Mairesse, J., 1998. Research, Innovation and Productivity: An econometric analysis at the firm level. Economics of Inovation and New Technology, 7, 115-158.

Chapman, R.L. and Corso, M., 2005. From continuous improvement to collaborative innovation: the next challenge in supply chain management. Production Planning \& Control, 16, 339 - 344.

Duclos, L.K. Vokukra, R.J. and Lummus, R.R., 2003. A conceptual model of supply chain flexibility. Industrial management and data Systems, 103, 446-456.

Edquist, C., 2005. Systems of Innovation: Perspectives and challenges. In: J. Fagerberg, eds. The Oxford Handbook of Innovation. New York: Oxford University Press, 181-208.

Feller, J. Hirvensalo, A. and Smeds, R., 2005. Inter-partner process learning in collaborative R\&D a case study from the telecommunications industry. Production Planning \& Control, 16, 388 395. 
Freel, M., 2000. External linkages and product innovation in small manufacturing firms. Entrepreneurship and Regional Development, 12, 245 - 266.

Furlan, A. Romano, P. and Camuffo, A., 2006. Customer-supplier integration forms in the airconditioning industry. Journal of Manufacturing Technology Management, 17, 633-655.

Ganotakis, P. and Love, J.H., 2011. R\&D, product innovation and exporting: evidence from UK new technology based firms. Oxford Economic Papers, 63, 279 - 306.

Ganotakis, P. and Love, J.H., forthcoming. The innovation value chain in new technology based firms: Evidence from the UK. Journal of Product Innovation Management

Global Competitiveness Report., 2010. World Economic Forum. Geneva, Switzerland.

Greene, W.H., 2005. Econometric Analysis. $5^{\text {th }}$ ed. New Jersey: Prentice-Hall.

Grossman, G. and Helpman, E., 1998. Innovation and Growth in the World Economy. Cambridge, MA: MIT Press.

Hakansson, H. and Snehota, I., 1989. No business is an island. Scandinavian Journal of Management, 5, 187 - 200.

Hansen, M.T. and Birkenshaw, J., 2007. The innovation value chain. Harvard Business Review, June, $121-130$.

Hughes, A. and Wood, E., 2000. Rethinking innovation comparisons between manufacturing and services: the experience of the CBR SME surveys in the UK. In: J.S. Metcalfe and I. Miles, eds. Innovation Systems in the Service Economy. Measurement and Case Study Analysis. Boston: Kluwer Academic Publishers, 105-124.

Koufteros, X. Vonderembse, M. and Jayaram, J., 2005. Internal and external integration for product development: The contingency effects of uncertainty, equivocality, and platform strategy. Decision Sciences, 36, 97 - 133. 
Leiponen, A., 2005. Organization of knowledge and innovation: The case of Finnish business services. Industry and Innovation, 12, 185-203.

Malhotra, A. Gosain, S. and ElSawy, O.A., 2005. Absorptive capacity configurations in supply chains: gearing for partner-enabled market knowledge creation. MIS Quarterly, 29, 145 - 187.

Mansfield, E., 1995. Academic research underlying industrial innovations: sources, characteristics and financing. Review of Economics and Statistics, 77, 55-65.

Nambisan, S., 2003. Information Systems as a reference for New Product Development. MIS Quarterly, 27, 1 - 18.

Vipul Jain, S. Wadhwa, S. and Deshmukh, S.G., 2009. Revisiting information systems to support a dynamic supply chain: issues and perspectives. Production Planning \& Control, 20, 17-29.

Petersen, K.J. Handfield, R.B. and Ragatz, G.L., 2003. A Model of supplier integration into new product development. Journal of Product Innovation Management, 20, 284 - 299.

Pero, M. Abdelkafi, N. Sianesi, A. and Blecker, T., 2010. A framework for the alignment of new product development and supply chains. Supply Chain Management: An International Journal, $15,115-128$.

Ragatz, G.L. Handfield, R.B. and Petersen, K.J., 2002. Benefits associated with supplier integration into new product development under conditions of technology uncertainty. Journal of Business Research, 55, $389-400$.

Roper, S. and Hewitt-Dundas, N., 2005. Measuring the Impact of Grant Support for Innovation: Panel Data Evidence for Irish Firms. European Regional Science Association, Amsterdam.

Roper, S. Du, J. and Love, J.H., 2008. Modelling the innovation value chain. Research Policy, 37, 961-977.

Roper, S. and Hewitt-Dundas, N., 2011. Path dependency and innovation: Evidence from matched patents and innovation panel data. DRUID Conference, Denmark. 
Rungtusanatham, M. and Forza, C., 2005. Coordinating product design, process design, and supply chain design decisions. Part A: Topic motivation, performance implications, and article review process. Journal of Operations Management, 23, 257 - 265.

Santoro, M.D., 2000. Success breeds success: The linkage between relationship intensity and tangible outcomes in University-Industry collaborative ventures. Journal of High Technology Management Research, 11, 255 - 273.

Sezen, B., 2008. Relative effects of design, integration and information sharing on supply chain performance. Supply Chain Management: An International Journal, 13, 233 - 240.

Soosay, C. Hyland, P. and Ferrer, M., 2008. Supply Chain Collaboration: Capabilities for Continuous Innovation. Supply Chain Management: An International Journal, 13, 160-169.

Stroeken, J.H.M., 2000. Information technology, innovation and supply chain structure. International Journal of Technology Management, 20, 156 - 175.

Taiwan Ministry of Economic Affairs., 2001. High technology industries in Taiwanese economics.

Ulrich, K. and Eppinger, S.D., 2000. Product design and development. New York: McGraw-Hill.

Verdecho, M.J. Alfaro, J.J. and Rodriguez, R., 2009. Foundations for collaborative performance measurement. Production Planning \& Control, 20, 193 - 205.

Wong, P.K., 1992. Technological development through subcontracting linkages: evidence from Singapore. Scandinavian International Business Review, 1, 28-40.

Wynstra, F. and Pierick, E., 2000. Managing supplier involvement in new product development: a portfolio approach. European Journal of Purchasing \& Supply Management, 6, 49 - 57.

Williamson, O.E., 1975. Markets and hierarchies: Analysis and anti-trust implications. A study in the economics of internal organization. New York: The Free Press. 
Table 1. Summary Statistics and variable description

\begin{tabular}{|c|c|c|c|c|}
\hline \multirow[t]{2}{*}{ Variable description } & \multicolumn{2}{|c|}{ High tech firms } & \multicolumn{2}{|c|}{ Whole sample } \\
\hline & Mean & S.D. & Mean & S.D. \\
\hline \multicolumn{5}{|l|}{ Innovation variables } \\
\hline Patent registration - Firm has registered a patent $(0 / 1)$ & 0.52 & 0.499 & 0.45 & 0.498 \\
\hline Design/Copyright registration - Firm has registered a design or copyright (0/1) & 0.457 & 0.498 & 0.445 & 0.497 \\
\hline $\begin{array}{l}\text { Process Innovation - Firm introduced an innovative process for producing or distributing } \\
\text { products }(0 / 1)\end{array}$ & 0.57 & 0.495 & 0.271 & 0.444 \\
\hline \multicolumn{5}{|l|}{ Information sourcing activities } \\
\hline Internal R\&D - R\&D undertaken within the firm (0/1) & 0.85 & 0.355 & 0.82 & 0.383 \\
\hline $\begin{array}{l}\text { External R\&D - R\&D undertaken outside the firm in the form of totally outsourced } \\
\text { contracts }(0 / 1)\end{array}$ & 0.29 & 0.454 & 0.297 & 0.457 \\
\hline Collaborative agreements / information sharing with customers (0/1) & 0.74 & 0.437 & 0.72 & 0.444 \\
\hline Collaborative agreements / information sharing with suppliers (0/1) & 0.7 & 0.457 & 0.5333 & 0.5 \\
\hline $\begin{array}{l}\text { Collaborative agreements / information sharing with other than customer/suppliers } \\
\text { companies }(0 / 1)\end{array}$ & 0.626 & 0.484 & 0.593 & 0.491 \\
\hline $\begin{array}{l}\text { Collaborative agreements / information sharing with universities/ research institutions } \\
(0 / 1)\end{array}$ & 0.435 & 0.496 & 0.357 & 0.479 \\
\hline \multicolumn{5}{|l|}{ Firm Structure - Information systems } \\
\hline $\begin{array}{l}\text { Information Systems- Firms with high usage of information systems designed } \\
\text { specifically for supporting sharing of knowledge and information with external parties } \\
(0 / 1)\end{array}$ & 0.175 & 0.38 & 0.027 & 0.163 \\
\hline $\begin{array}{l}\text { Structure - Firms that an organizational structure that assists inter-departmental } \\
\text { communication is highly diffused within the firm }(0 / 1)\end{array}$ & 0.13 & 0.336 & 0.044 & 0.205 \\
\hline \multicolumn{5}{|l|}{ Resources } \\
\hline Employment (number) & 270.28 & 824.58 & 111.435 & 449.76 \\
\hline Part of a group $(0 / 1)$ & 0.16 & 0.369 & 0.128 & 0.334 \\
\hline Firm age $(0 / 1)-(1=$ less than three years, $0=$ three years or more $)$ & 0.0527 & 0.22 & 0.0677 & 0.251 \\
\hline Percentage of workforce with degree (\%) & 45.41 & 28.7 & 41.48 & 32.02 \\
\hline Training - Employees have received training related to introduction of innovations (0/1) & 0.81 & 0.39 & 0.745 & 0.435 \\
\hline \multicolumn{5}{|l|}{ Government assistance } \\
\hline Government assistance on R\&D for product/process (0/1) & 0.59 & 0.492 & 0.65 & 0.476 \\
\hline \multicolumn{5}{|l|}{ Market strategy } \\
\hline Exporter - Whether a firm has a consistent presence in foreign markets $(0 / 1)$ & 0.74 & 0.435 & 0.381 & 0.485 \\
\hline Specific - Products are made to a serve a specialist niche market $(0 / 1)$ & 0.18 & 0.385 & 0.065 & 0.247 \\
\hline
\end{tabular}


Figure 1. Network of relationships between information sources

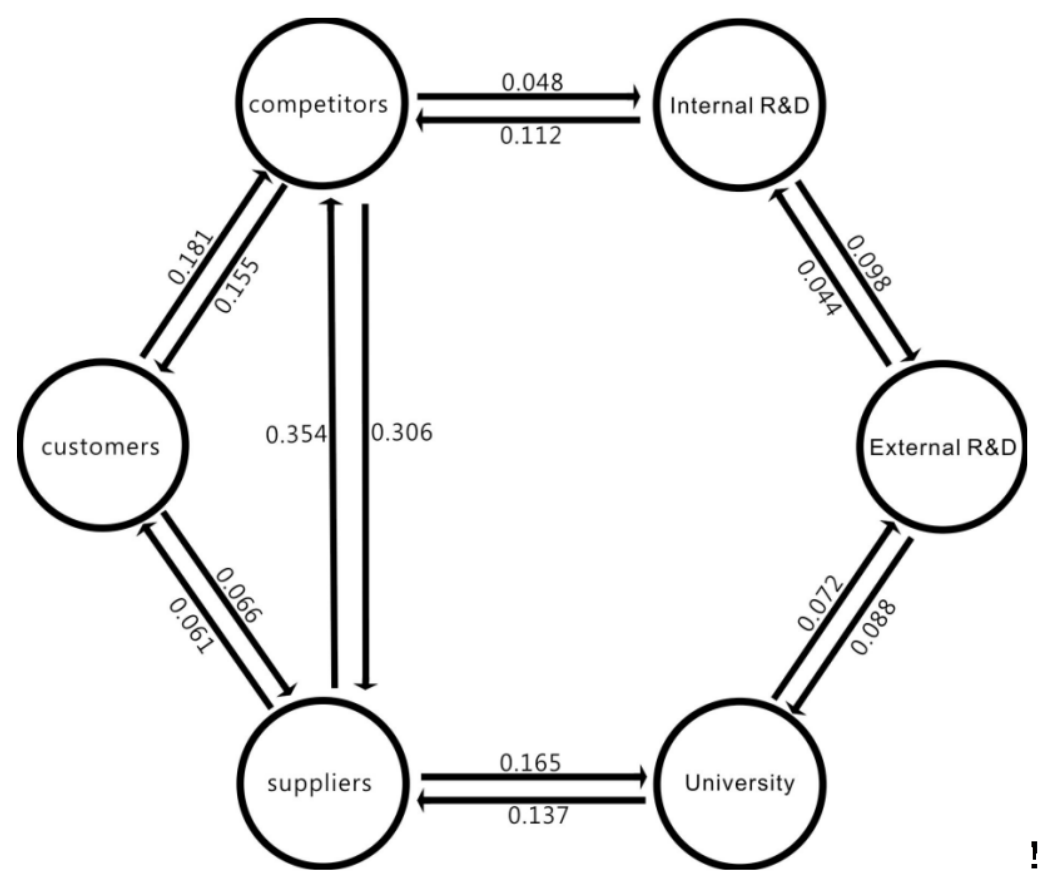

Figure 2. Relationships between information sources and innovation outputs Knowledge Sourcing

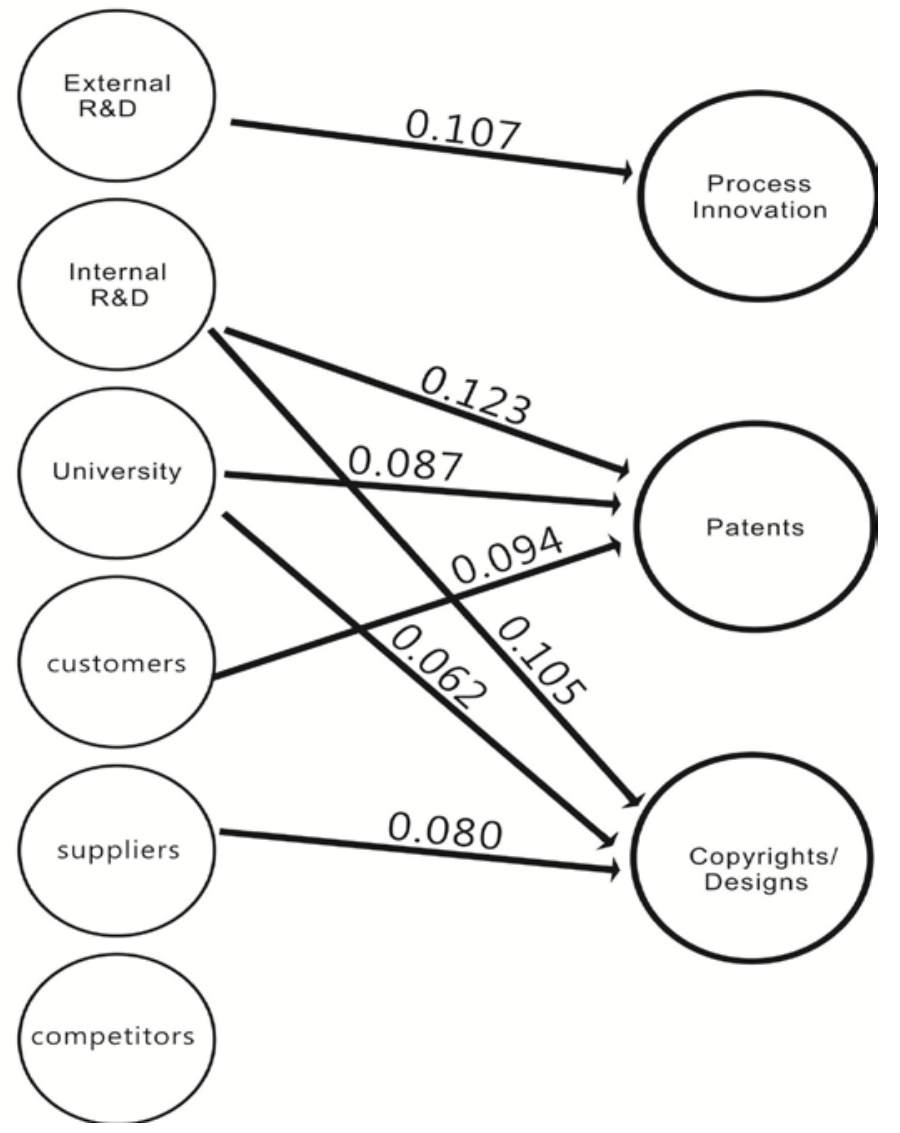


Table 2. Information sourcing equations

\begin{tabular}{|c|c|c|c|c|c|c|}
\hline Variables & Internal R\&D & External R\&D & Customers & Suppliers & Other Companies & $\begin{array}{c}\text { Universities/ } \\
\text { Research Institutes }\end{array}$ \\
\hline \multicolumn{7}{|l|}{ Information Sources } \\
\hline Internal R\&D (0/1) & - & $0.0983 * *(0.0422)$ & $-0.0164(0.0427)$ & $0.0329(0.0462)$ & $0.112 * *(0.05)$ & $0.0482(0.5)$ \\
\hline External R\&D (0/1) & $0.0444 * *(0.0209)$ & . & $0.0257(0.0328)$ & $-0.1(0.0353)$ & $0.0054(0.0378)$ & $0.0883 * *(0.0383)$ \\
\hline Collaboration with customers & $-0.0041(0.0266)$ & $0.03(0.0354)$ & - & $0.066 *(0.0373)$ & $0.181^{* * *}(0.04)$ & $0.0135(0.04)$ \\
\hline Collaboration with suppliers & $0.0139(0.0233)$ & $-0.004(0.038)$ & $0.0613 *(0.037)$ & - & $0.354 * * *(0.037)$ & $0.165 * * *(0.0392)$ \\
\hline Collaboration with other companies & $0.0476 * *(0.0227)$ & $0.0014(0.035)$ & $0.155 * * *(0.0344)$ & $0.306^{* * *}(0.0336)$ & - & $0.00987(0.0385)$ \\
\hline $\begin{array}{l}\text { Collaboration with universities/ } \\
\text { research institutions }\end{array}$ & $0.0181(0.021)$ & $0.0721 * *(0.0326)$ & $0.001(0.0313)$ & $0.137 * * *(0.0318)$ & $0.012(0.0355)$ & - \\
\hline \multicolumn{7}{|l|}{$\begin{array}{l}\text { Information systems/ } \\
\text { inter-functional collaboration }\end{array}$} \\
\hline Information systems & $0.057 * *(0.0222)$ & $0.0158(0.0354)$ & $0.0483(0.0332)$ & $0.086^{* *}(0.0349)$ & $-0.0145(0.0387)$ & $0.0922 * *(0.0381)$ \\
\hline Inter-functional collaboration & $-0.0014(0.0236)$ & $0.0458(0.0345)$ & $0.01(0.0333)$ & $0.0468(0.0353)$ & $0.0414(0.0378)$ & $0.00348(0.0378)$ \\
\hline \multicolumn{7}{|l|}{ Firm Resources } \\
\hline Employment & $0.00025^{* * *}(0.00006)$ & $-0.00001(0.00004)$ & $0.000016(0.00004)$ & $0.000012(0.00004)$ & $0.000006(0.00004)$ & $0.000077 *(0.00005)$ \\
\hline Employment squared & $-1.18 \times 10^{* * *} *^{-8}(0.00)$ & $-2.05 \times 10^{-9}(0.00)$ & $-8.22 \times 10^{-12}(0.00)$ & $-1.25 \times 10^{-10}(0.00)$ & $6 \times 10^{-10}(0.000)$ & $-1.87 \times 10^{-9}$ \\
\hline Part of group of firms & $-0.0269(0.0327)$ & $-0.0317(0.0428)$ & $-0.0195(0.043)$ & $-0.0557(0.0467)$ & $0.0075(0.0473)$ & $-0.0116(0.0483)$ \\
\hline Firm age & $0.0605 * *(0.0279)$ & $0.103(0.0751)$ & $0.0817(0.0576)$ & $0.06(0.0615)$ & $-0.17 * *(0.079)$ & $0.113(0.079)$ \\
\hline Workforce with degrees & $0.00016(0.00038)$ & $0.00071(0.00058)$ & $-0.0007(0.00056)$ & $-0.000022(0.00059)$ & $0.00065(0.00064)$ & $-0.000525(0.00065)$ \\
\hline Trained workforce & $0.0524 *(0.0298)$ & $0.016(0.0408)$ & $0.0148(0.04)$ & $0.0951 * *(0.043)$ & $-0.0121(0.0443)$ & $0.0075(0.0455)$ \\
\hline \multicolumn{7}{|l|}{ Governmental assistance } \\
\hline Assistance on R\&D for products & $-0.00125(0.0212)$ & $0.071^{* *}(0.0319)$ & $-0.02(0.0312)$ & $-0.123^{* * *}(0.0319)$ & $0.0465(0.0362)$ & $0.0318(0.0359)$ \\
\hline \multicolumn{7}{|l|}{ Marketing Strategy } \\
\hline Exporter & $0.0897 * *(0.0295)$ & $0.0349(0.037)$ & $0.0611(0.0374)$ & $0.0273(0.0389)$ & $-0.00005(0.0424)$ & $0.044(0.0415)$ \\
\hline Observations & 862 & 862 & 862 & 862 & 862 & 862 \\
\hline Log-Likelihood & -317.046 & -509.122 & -473.812 & -436.44 & -500.294 & -561.546 \\
\hline
\end{tabular}

Notes: Standard errors in parentheses; ${ }^{* * *} \mathrm{p}<0.001,{ }^{* *} \mathrm{p}<0.05,{ }^{*} \mathrm{p}<0.1$. Coefficients are marginal effects. 
Table 3. Innovation output equations

\begin{tabular}{|c|c|c|c|}
\hline Variables & Process Innovation & Patents & $\begin{array}{c}\text { Copyrights/Registered } \\
\text { Designs } \\
\end{array}$ \\
\hline \multicolumn{4}{|l|}{ Information Sources } \\
\hline Internal R\&D (0/1) & $-0.0259(0.0484)$ & $0.123 * *(0.0519)$ & $0.105^{* *}(0.0523)$ \\
\hline External R\&D (0/1) & $0.107 * * *(0.0369)$ & $0.0475(0.0388)$ & $-0.0229(0.0391)$ \\
\hline Collaboration with customers & $-0.045(0.039)$ & $0.0943 * *(0.0411)$ & $0.0595(0.0412)$ \\
\hline Collaboration with suppliers & $0.007(0.0417)$ & $0.0126(0.0434)$ & $0.0797 *(0.042)$ \\
\hline Collaboration with other companies & $-0.0237(0.0383)$ & $-0.0144(0.0399)$ & $-0.0272(0.0395)$ \\
\hline $\begin{array}{l}\text { Collaboration with universities/ } \\
\text { research institutions }\end{array}$ & $-0.0059(0.0356)$ & $0.0869 * *(0.0363)$ & $0.0617 *(0.0365)$ \\
\hline \multicolumn{4}{|c|}{ Information systems/inter-functional collaboration } \\
\hline Information systems & $0.0835 * *(0.0378)$ & $0.0945 * *(0.0387)$ & $0.119 * * *(0.038)$ \\
\hline Inter-functional collaboration & $0.0834 * *(0.0372)$ & $0.044(0.0386)$ & $0.043(0.0385)$ \\
\hline \multicolumn{4}{|l|}{ Firm Resources } \\
\hline Employment & $0.00007(0.00005)$ & $0.000083(0.0005)$ & $0.000045(0.00009)$ \\
\hline Employment squared & $-6.18 \times 10^{-9} * * *(0.00)$ & $-3 \times 10^{-9}(0.00)$ & $3.31 \times 10^{-8}(0.00)$ \\
\hline Firm age & $-0.0262(0.0775)$ & $-0.142 *(0.0793)$ & $0.0555(0.08)$ \\
\hline Part of group of firms & $-0.0712(0.0477)$ & $-0.132 * * *(0.0484)$ & $-0.0788(0.048)$ \\
\hline Percentage of workforce with degrees & $-0.0001(0.00064)$ & $0.00045(0.00066)$ & $0.00146 * *(0.00066)$ \\
\hline Trained workforce & $-0.0166(0.0445)$ & $0.0239(0.0465)$ & $0.0336(0.0472)$ \\
\hline \multicolumn{4}{|l|}{ Governmental assistance } \\
\hline Assistance on R\&D for products & $0.0533(0.036)$ & $-0.0412(0.0375)$ & $-0.0354(0.036)$ \\
\hline \multicolumn{4}{|l|}{ Marketing Strategy } \\
\hline Exporter & $-0.0446(0.04)$ & $0.1^{* *}(0.0422)$ & $0.0293(0.0428)$ \\
\hline Niche market & $-0.0343(0.0457)$ & $0.125 * * *(0.046)$ & $0.092 * *(0.0458)$ \\
\hline Observations & 862 & 862 & 862 \\
\hline Log-Likelihood & -564.44 & -545.232 & -554.979 \\
\hline
\end{tabular}

Notes: Standard errors in parentheses; ${ }^{* * *} \mathrm{p}<0.001,{ }^{* *} \mathrm{p}<0.05,{ }^{*} \mathrm{p}<0.1$. Coefficients are marginal effects. 